\title{
PÁlYAKEZDŐ PEDAGÓGUSOK KARRIERTERVEI
}

\section{ZUBORA MÁRTA* - HOLIK ILDIKó**}

\author{
* a Kodály Zoltán Ének-zenei Általános Iskola, Gimnázium és Zenei AMI tanára \\ zubora.marta@yahoo.com \\ ** az Óbudai Egyetem Trefort Ágoston Mérnökpedagógiai Központjának adjunktusa \\ holik.ildiko@tmpk.uni-obuda.hu
}

$\overline{\text { A pályakezdö pedagógusok sajátos helyzetben vannak a munkaeröpiacon, hiszen az életpálya }}$ modell gyakornoki fokozatában számos kihivással, problémával kell megküzdeniük. Kutatásunk arra irányult, hogy megvizsgáljuk és megismerjük a pályakezdö pedagógusok karrierterveit, hogy mennyire elégedettek az iskolai munka feltételeivel, a karrierlehetöségekkel, terveznek-e pályaelhagyást, illetve hogyan látják jövöjüket a pedagógus-életpályamodellben.

\section{Bevezető}

Sok más pályával ellentétben a pedagóguspályán egyáltalán nem beszélhetünk korai felfutású vagy gyors karrierről, hiszen az életpályamodell szakaszai szerint halad. A 2011. évi CXC. (a nemzeti köznevelési) törvény 64. § (4) bekezdése öt fokozatba sorolja a pedagógus munkakörben foglalkoztatottakat. ${ }^{1}$

A minősítési rendszer két központi eleme a minősítő vizsga és a minősítési eljárás (Útmutató, 2013). Minősítő vizsgát a diploma megszerzését követő második gyakornoki év végén tesz a pedagógusgyakornok a Pedagógus I. cím elnyeréséért. A többi életpálya-fokozat az ún. minősítési eljárást követően érhető el (326/2013. (VIII. 30.) Korm. rendelet, 2. §).

Kutatásunk arra keresi a választ, hogy milyen karrierterveik vannak a pályájukat most kezdő pedagógusoknak Magyarországon, milyen tervekkel indulnak neki az iskolai munkának, mennyire elégedettek a karrierlehetőségekkel, illetve hogyan látják jövőjüket a pedagógus-életpályamodellben.

\footnotetext{
${ }^{1}$ „A pedagógus-munkakörben foglalkoztatott az általa megszerzett legmagasabb, a munkakör ellátásához e törvényben előírt iskolai végzettség, valamint állam által elismert szakképesítés, szakképzettség, továbbá a nevelő, oktató munkája ellátásához közvetlenül kapcsolódó, azt közvetlenül segítő doktori cím, tudományos fokozat, valamint akadémiai tagság, szakmai gyakorlat, publikációs tevékenység, minősítő vizsga és a minősítési eljárás keretében elnyert minősítés alapján a) Gyakornok, b) Pedagógus I., c) Pedagógus II., d) Mesterpedagógus, e) Kutatótanár fokozatokat érheti el.” (2011. évi CXC. (a nemzeti köznevelési) törvény $64 . \S$ (4) bekezdés)
} 


\section{A pályakezdő pedagógusokról}

A pedagógusok pályájuk során sajátos utat járnak be. David C. Berliner (Berliner, 2005) amerikai kutató egy ötlépcsős fejlődési modellben írta le, hogy a pedagógus milyen utat tehet meg pályája során. Az öt fejlődési szakaszt Berliner (Berliner, 2005) a következö, főként gondolkodási folyamatokra utaló elnevezésekkel írta le: újonc, középhaladó, kompetencia (racionalitás szintje), jártas (intuitív), szakértő (nem-racionális). Fontos azonban, hogy nem minden tanár járja végig az összes szakaszt és többségük nem jut el a szakértői szintig.

Berliner felosztásában a pályakezdő pedagógus megközelítőleg az újonc és a középhaladó szinthez sorolható. Az újonc szerep körülbelül egy évig tart. „Ennek során megtanulja az elvégzendő feladatokat részekre bontani, címkézni és begyakorolni. A gyakorlatszerzés idején viselkedése általában racionális, rugalmatlan, próbál igazodni a szabályokhoz." (idézi: Köcséné, 2009). A másodikharmadik évben jut el a tanár a középhaladó szintre, ahol a gyakorlati tudás kapcsolatba kerül az elméleti tudással, kontextusfüggő gyakorlati tudás kezd kialakulni, mérlegelni kezd a tanár, hogy az adott szituációban a szabálykövetés vagy a szabályszegés a célravezetőbb.

A pályakezdőknél a kezdeti időszak az idealizmus szakasza. Az egyetemről kikerülve, telve optimizmussal, a tudással felvértezve a kezdő felnagyítja a pálya szépségeit, úgy érzi, hogy a problémákat meg tudja oldani, nagyon motivált. Feltétlen bizalommal fordul a kollégái felé, bennük, a szülőkben és a gyerekekben is partnereket lát (Kolozsváry, 2006). A későbbiekben már (személyes tapasztalatok birtokában) észreveszi a munka buktatóit, érzékeli, hogy nem csak jóindulat veszi körül, kudarcokat kell elviselnie. Ez a szakasz a realizmus szakasza.

Falus Iván (Falus, 2006) szerint is összetett folyamat zajlik le a pályakezdőben a tanárrá válása során, amelyet számos tényező is nehezít: a kellő önismeret, a szakmai identitás hiánya, továbbá hogy még nem kellően szilárdultak meg alapvető kompetenciái, és (birtokában mindannak a korszerü tudásnak, amit az egyetemen kapott) be kell illeszkednie egy másik szervezet, az iskola életébe. Nehezíti a pályakezdő pedagógus helyzetét, hogy munkába állásakor megváltozik a jogi státusza, egy intézmény felelősségteljes munkavállalója lesz, akire akár hét-nyolc tanulócsoportot fejlesztését bízzák. Olyan tanítási és életszituációkba kerül, amelyeket eddig nem tapasztalt meg, sem az egyetemen, sem a tanítási gyakorlaton. Általában teljes munkaidőben tanít, minden új számára: ismerkedik a követelményekkel, a tananyaggal, a taneszközökkel, a lehetőségekkel. A pályakezdőnek a tanári mesterséget főként a „terepen” kell megtanulnia, ahol „,bedobják a mélyvízbe”, és „vagy megtanul úszni, vagy elsüllyed” („sink or swim") (Imre és Nagy, 2004). Mindezek alapján a kezdő tanár helyzete stresszel teli helyzet. A feszültségektől terhes környezet hatására alakulhat ki az ún. „valóság sokk” (Falus, 2010), amely sok kezdő pedagógust elriaszt a tanári pályától. 
Nagy Mária (Nagy, 2004) és munkatársai egy teljes éven át követték figyelemmel tizenhárom pályakezdő első évét kilenc munkacsoportban. Interjúk, óramegfigyelések, dokumentumelemzések, fénykép- és videofelvételek segítségével arra keresték a választ, mi a munkahelyre lépés első élménye, mik a pályakezdők reflexiói az első napokra, hetekre, hónapokra, milyen segítséget kapnak a pályakezdők. A kutatók azt tapasztalták, hogy szinte mindegyik pályakezdőt rögtön „bedobták a mély vízbe”. Teljes óraszámban tanítottak, olyan osztályokat bíztak rájuk, akiktől a tapasztaltabb kollégáik szabadulni akartak. Alig kaptak segítséget, az is csak többnyire az adminisztrációval volt kapcsolatos. Óráikat nem látogatták, vagy ha bement is az igazgató vagy egy ezzel megbízott tanár a pályakezdő órájára, azt részletesen nem elemezték. Miközben teljes állásban, a kollégáikkal azonos munkát végeztettek velük mégsem tartották őket „kész”, felkészült tanárnak, mert érettségiző osztályt vagy kezdő osztályt (ahol a közösségépítés fontos feladat) nem adtak nekik. Bár tudatos mentorálást nem kaptak, mégis fejlődtek a pályakezdők: különbözö iskolai szituációkban figyelték meg a kollégáikat, de többnyire a „saját kárukon" tanultak. Ritkán kérdeztek a tapasztaltabb kollégáktól. Sematikus tanácsokat kaptak például, hogy „,szigorúan taníts”, de hogy hogyan, azt nem. Néha a diákok adtak nekik tanácsokat. A kutatókkal azonban meg tudták beszélni a nehézségeiket.

A fenti problémák miatt egyre nagyobb figyelem fordul a pályakezdő pedagógusok támogatására és folyamatos szakmai fejlődésük elősegítésére hazánkban (Szivák, 1999; Falus, 2004; Nagy, 2004; Holik, 2015) és nemzetközi szinten (Karras - Wolhuter, 2015). Világszerte különféle támogatási rendszereket vezettek be, amelyek tapasztalatai arra mutattak rá, hogy a bevezető szakasz szerves részét képezi a tanárok egész pályafutására kiterjedő felkészítésének. (Hunya és Simon, 2013) Az EU szakértői csoportjának vizsgálata rávilágított arra, hogy a pályakezdő tanároknak háromféle segítségre van szükségük a bevezető szakasz ideje alatt (Falus, 2010):

1. személyes segítségre, melyek legföbb szerepe a tanári identitás kialakulásának támogatásában van;

2. társas segítségre, mely célja, hogy a tanár az iskolai és a szakmai közösség egyenrangú tagjává váljon; illetve

3. professzionális segítségre, mely a szakmai készségek, képességek, kompetenciák kialakulását segíti.

A segítségnyújtás a mentorálás, a szakértői támogatás, a társak és az önelemzés rendszerének együttes hatásán keresztül valósul meg (Stéger, 2010).

A bevezetó támogatás egyik alapeleme a mentorrendszer (Tordai, 2015). A mentorálás során egy tapasztalt és munkáját szakértői szinten végző pedagógus irányítja a tanárjelölt, illetve a pályakezdő kolléga tapasztalatszerzési folyamatát, és változatos eszközökkel ad visszajelzést a számára, segítve ezzel az önelemzö, 
önfejlesztő munkáját (Stéger, 2010). A mentor és a mentorált egyenrangú kapcsolatra épülő együttmüködése segíti az eredményes mentorálást (Sallai, 2015), valamint lehetővé teszi a felsőoktatási intézmény elméleti képzése és az iskolai gyakorlat közötti szakadék áthidalását (Szücs és Fejes, 2010).

A mentorral kialakított bizalmi kapcsolat hosszú időre meghatározhatja a kezdő tanár szerepértelmezését, valamint a pályához való attitüdjét. Kiemelkedő fontosságú az érzelmi és pszichológiai támogatás, amely hosszú távon csökkentheti a kezdeti kudarcok és a „valóságsokk” negatív hatásaiból eredő pályaelhagyást (Szivák, 1999).

„A mentornak fontos szerepe van a tanári pályára való szocializálódási folyamatban (Kubinger-Pillmann, 2011), az új szakmai közösségbe való beilleszkedés támogatásában, továbbá példaként szolgál a jelölt számára a korszerü pedagógiai módszerek alkalmazása, illetve a folyamatos tanulás, fejlődés igényének kialakítása terén is (Szivák, Lénárd és Rapos, 2011). Tehát a mentortanárok a modell (minta), a szakértő konzultáns és a tanácsadó (Lesznyák, 2005) szerepét töltik be a pályakezdő pedagógusok felkészítésében.

\section{A kutatás jellemzői}

Jelen kutatás arra irányult, hogy felmérje a pályakezdő pedagógusok, azaz a gyakornokok karrierterveit, illetve az esetleges pályamódosítási szándékaikat.

A vizsgálat célcsoportját a gyakornok besorolású, vagyis nem több mint két éve, tanítói vagy tanári végzettséggel dolgozó pályakezdő pedagógusok alkották függetlenül attól, hogy főállásban, teljes- vagy rész munkaidőben dolgoznak. A kutatásban kizárólag olyan kezdő pedagógusok vettek részt, akik a 2011. évi CXC. köznevelési törvény szerinti köznevelési intézményekben dolgoznak (általános iskolában, gimnáziumban, szakközépiskolában, valamint a szakoktatásban, az alapfokú művészetoktatásban, a kollégiumi ellátásban, a Köznevelési Hídprogramok keretében, a felnőttoktatásban, a fejlesztő nevelés-oktatásban és a pedagógiai szakszolgálatoknál).

A kutatás kérdőívének összeállításánál alapul vettük Chrappán Magdolna (Chrappán, 2010) tanulmányát, melyben a 2010. évi Diplomás Pályakövető Rendszer (DPR) kutatás eredményeit foglalta össze. Vizsgálatunkat az alábbi kutatási kérdések mentén végeztük:

1. Mennyire elégedettek a megkérdezett gyakornokok a pedagógusi pálya karrierlehetöségeivel?

2. A pedagógusi pályán képzelik-e el a jövőjüket?

3. Milyen karrierterveik vannak a pedagógus-életpályamodellben?

4. Azok a pályakezdő pedagógusok, akik tudatosan készültek a pedagógusi pályára, hosszú távon is itt tervezik-e karrierjüket? 


\section{A vizsgálati minta}

2014. november 20. és 2015. január 6. között 476 pályakezdő pedagógus (gyakornok) töltötte ki kérdőívünket anonim módon, önkéntes alapon (papíralapú vagy online kérdőív formájában). A megkérdezettek $21 \%$-a volt férfi és $79 \%$-a nő. A kérdőívet kitöltők életkori megoszlását az 1. táblázat tartalmazza.

1. táblázat: A válaszadó gyakornokok életkori megoszlása (N: 474 fö)

\begin{tabular}{|l|l|l||l|l|l|l|}
\hline $\begin{array}{c}\text { Gyakornokok } \\
\text { életkora }\end{array}$ & $\begin{array}{c}\text { Gyakornokok } \\
\text { száma (fó) }\end{array}$ & $\begin{array}{c}\text { Aránya az } \\
\text { ossszes } \\
\text { gyakornok } \\
\text { között }\end{array}$ & $\begin{array}{c}\text { Férfi } \\
(f o ̈)\end{array}$ & $\begin{array}{c}\text { Aránya a } \\
\text { férfiak } \\
\text { között }\end{array}$ & $\begin{array}{c}\text { Nö } \\
(f o ̈)\end{array}$ & $\begin{array}{c}\text { Aránya a } \\
\text { nök } \\
\text { között }\end{array}$ \\
\hline $22-25$ éves & 188 & $39,66 \%$ & 27 & $26,73 \%$ & 161 & $43,16 \%$ \\
\hline $26-29$ éves & 212 & $44,73 \%$ & 55 & $54,46 \%$ & 157 & $42,09 \%$ \\
\hline 30 év fölötti & 74 & $15,61 \%$ & 19 & $18,81 \%$ & 55 & $14,75 \%$ \\
\hline Összesen & 474 & $100 \%$ & 101 & $100 \%$ & 373 & $100 \%$ \\
\hline
\end{tabular}

A mintába került gyakornokok több mint fele, 258 fö (54\%) BA/BSc diplomával rendelkezik. 199 (42\%) gyakornoknak van MA/MSc diplomája. 19 fö (4\%) egyéb képzésben, például osztatlan képzésben részesült. A válaszadók döntő többsége nappali tagozaton végzett: 428 fö (90\%). 4 fö esti tagozaton, 42 fö $(9 \%)$ levelezö tagozaton, 2 fő pedig távoktatásban szerzett diplomát. A szakok szerint vizsgálva és csoportosítva a válaszadó gyakornokokat a három legnagyobb csoport a következő: 1. közismereti tanárok (humán, reál és nyelvtanár): 178 fö (38\%), 2. tanítók: 106 fö (23\%), 3. gyógypedagógusok/fejlesztő pedagógusok: 75 fő (16\%) (lásd 1. ábra).

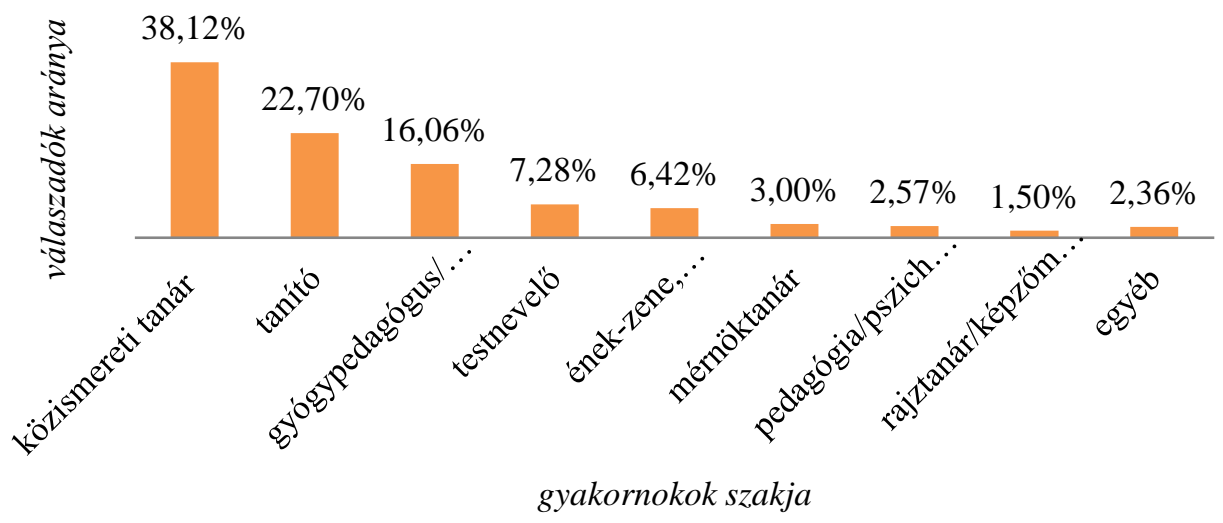

1. ábra: A gyakornokok végzett szakjai (N: 467 fö) 
A válaszadó gyakornokok több mint fele, 275 fö (58\%) általános iskolában, 59 fö (12\%) gimnáziumban, 45 fö (9\%) szakközépiskolában tanít. A szakoktatásban dolgozó gyakornokok száma: 15 fö (3\%). Az alapfokú müvészetoktatásban tanít 29 fö $(6 \%) .53$ fő (11\%) egyéb helyen dolgozik, például többcélú intézményben, gyógypedagógiai iskolában, kollégiumban, pedagógiai intézetben, speciális iskolában, vagy utazó gyógypedagógus. (Ennél a kérdésnél a válaszadók azt az egy iskolatípust jelölték meg, amely a legjellemzőbb a tevékenységükre.) A válaszadó pályakezdő pedagógusok fele, 238 fó (50\%) vidéki városban, 142 fö $(30 \%)$ Budapesten, 93 fö (20\%) pedig községben tanít.

Figyelemreméltó adat, hogy a megkérdezett gyakornokok csupán 70\%-ának, 328 fönek sikerült a diploma kézhezvétele után azonnal pedagógusként elhelyezkedni (2. ábra). A gyakornokok közel egyharmadának, 146 fónek (31\%) nem sikerült azonnal elhelyezkednie pedagógusként, vagyis a pályája látszólag rögtön akadályokba ütközött. $\mathrm{Az}$ alábbi adatokból láthatjuk, hogy milyen nehézségekkel találkoztak a megkérdezett gyakornokok rögtön a pályájuk kezdetén.

A 146 gyakornokból 137 válaszolt arra a kérdésre, hogy ha nem sikerült a diplomaszerzés után azonnal elhelyezkedni pedagógusként, annak mi volt az oka. Közülük 64 föt - elmondásuk szerint - azért nem vettek fel, mert nem volt üres álláshely. A 64-ből 13 válaszadó azt is hozzátette, hogy a munkáltatók kifejezetten tapasztalt, gyakorlattal rendelkező, esetleg férfi munkaerőt kerestek. 14 fö keresztfélévben végzett, azért nem talált tanév közben azonnal pedagógusként állást.

19 fő eleinte nem a tanári diplomájával helyezkedett el. 13 főnek hiányzott a nyelvvizsgája, vagyis nem is rendelkezett még tanári diplomával, amikor próbált elhelyezkedni. 12 fö egy másik szakmát, szakot, egyetemet kezdett el, illetve ketten $\mathrm{PhD}$ képzésbe fogtak. 6-an a tanulmányaik után rögtön gyermeket vállaltak, további 6 fö külföldre ment munka és nyelvtanulás céljából, vagyis nem is próbált pedagógusként elhelyezkedni. Három fő egyéb ok miatt nem tudott elhelyezkedni.

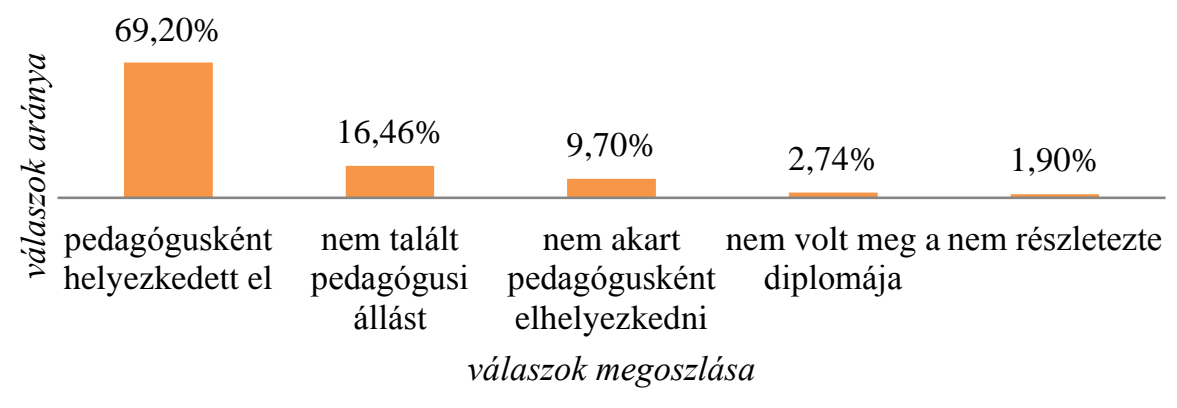

2. ábra: A diploma kézhezvétele után azonnal pedagógusként helyezkedett el? Ha nem, miért nem? (N: 474 fö) 
Jelenleg azonban mindannyian a közoktatásban dolgoznak. További figyelemreméltó adat, hogy a gyakornokok között 22 fö (5\%) nem a végzett szakját tanítja. Közülük öt kollégiumi tanár, nyolc napközis nevelő, kettő tanulószobai nevelö, a többi egyéb területen tevékenykedik (például hátrányos helyzetü gyerekeket mentorál, gépírást, nyelvet tanít stb.).

A mintára jellemzö, hogy kimagasló (81\%) azoknak az aránya, akik elsősorban azért választották a tanárszakot, mert érdekelte öket ez a szakterület, ezen a szakon akartak diplomát szerezni. Azok számaránya, akik elsősorban csak valamilyen diplomát akartak szerezni, csupán 5\%. A szülők és a környezet, illetve a munkahely elvárásai minimális mértékben motiválták őket a tanárszak választásában (1-1\%).

Paksi és munkatársai (Paksi és mtsai, 2015) gyakorló pedagógusok körében végzett kutatásukban szintén arra világítottak rá, hogy a pedagóguspályát tehát elsősorban azok választják, akikben megvan a pedagóguspálya iránti személyes érdeklődés. Kutatásuk alapján a leginkább meghatározó motivációs dimenziók: a „gyermekekkel/kamaszokkal való munka”, „gyermekek/kamaszok jövőjének alakítása”, valamint a „karrier intrinzik értéke”(amely a pedagógusi pályához kapcsolódó személyes érdeklődés és vágyak pályaválasztásra gyakorolt hatását méri).

Mennyire elégedettek a gyakornokok a karrierlehetöségekkel?

Kutatásunkban megvizsgáltuk, hogy mennyire elégedettek a pályakezdő pedagógusok a karrierlehetőségekkel, összehasonlítva a pedagógusi munka más aspektusaival (3. ábra). Eredményeink szerint a válaszadó pályakezdők közepes mértékben elégedettek a munkájuk tárgyi körülményeivel, vagyis az iskola felszereltségével, állapotával, ezektől lényegesen elégedettebbek a munkájuk szakmai tartalmával és személyi körülményeivel. A közepesnél gyengébb mértékben elégedettek, inkább elégedetlenek a pedagógusi pályán elérhető jövedelmükkel. A pedagóguspálya társadalmi megítélésével, a pálya presztízsével határozottan elégedetlenek - hasonlóan a pedagógusi diplomát szerezettek, illetve a már gyakorló pedagógusok körében végzett korábbi kutatások (Chrappán, 2010; Szabó, 1998; Holecz és Molnár, 2014; Holik, 2014) eredményeihez.

Erre a tényezőre azért is fontos odafigyelni, mivel a pályakezdés első két éve meghatározó lehet abból a szempontból, hogy valaki a pályán marad-e vagy sem: az elégedetlenség, a rossz közérzet, a feszültségekkel teli környezet elriaszthatja a pályakezdőket a pedagógusi pályától (Falus, 2010). 


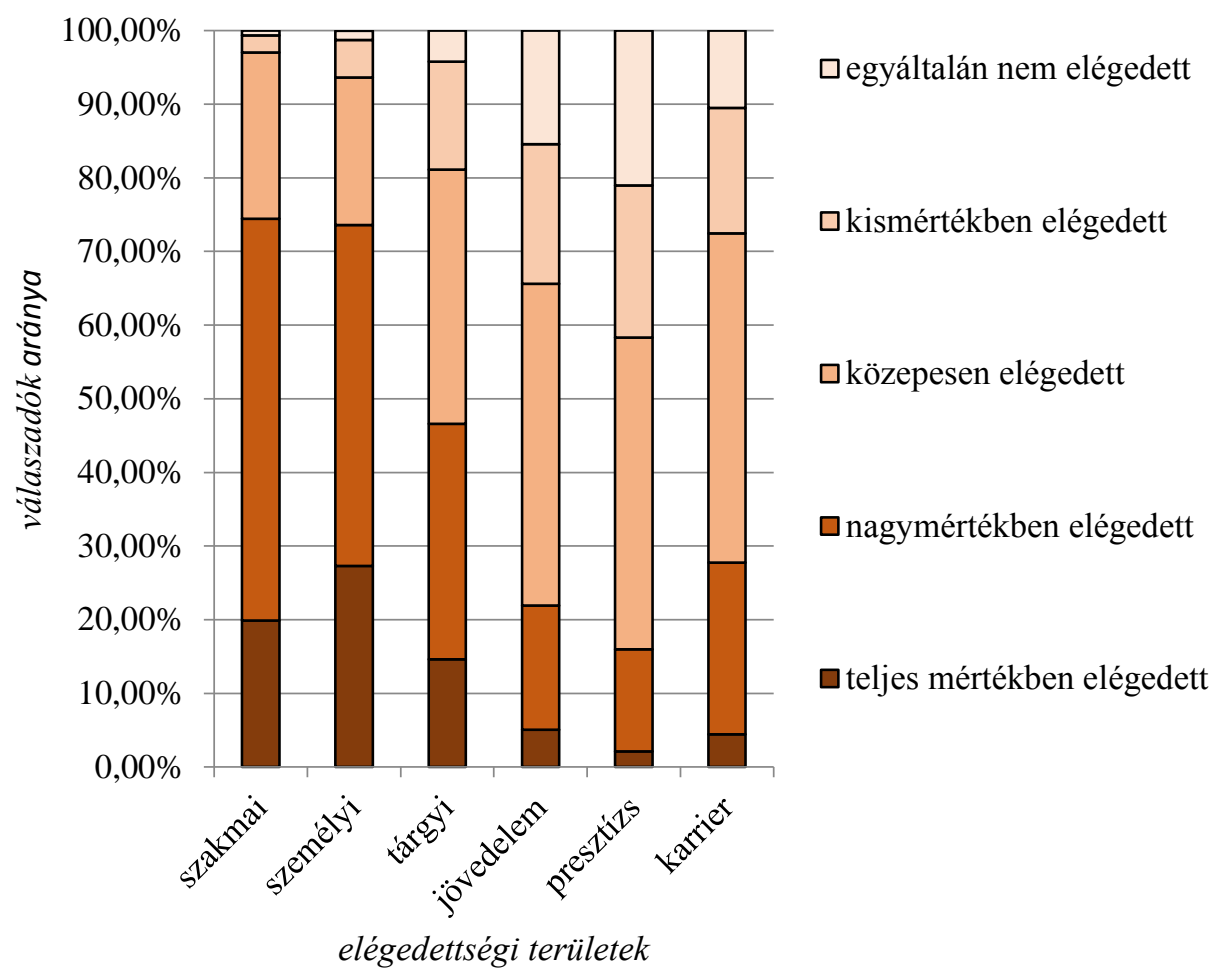

3. ábra: A vizsgált elégedettségi területek összehasonlítása (N: 476 fö)

Elgondolkodtató az az adat, hogy a válaszadó gyakornokoknak csupán alig több mint a negyede (28\%) elégedett teljes mértékben vagy nagymértékben a pályán elérhető karrierlehetőségekkel (4. ábra). Magas a közepesen elégedettek aránya, vagyis a válaszadó gyakornokok csak közepesen elégedettek a pedagógusi pályán elérhető karrierlehetőségekkel.

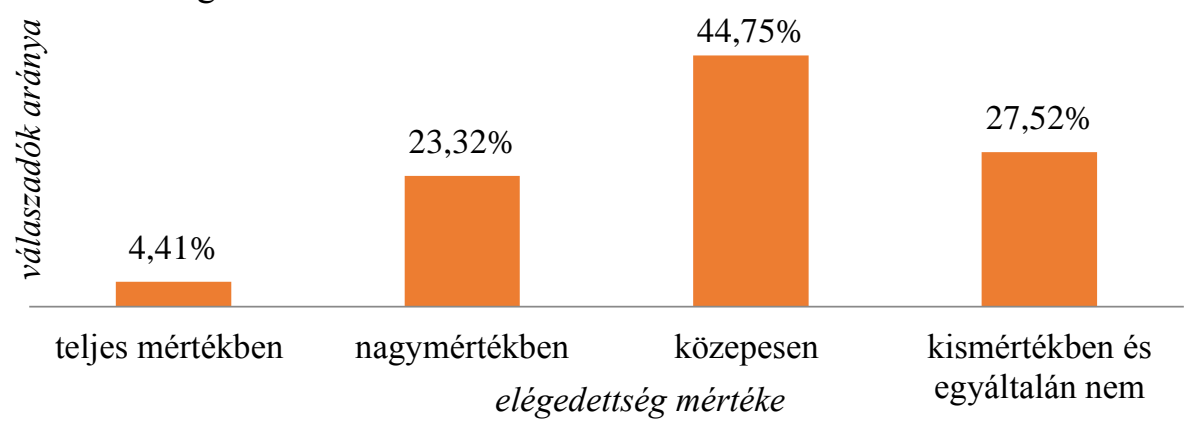

4. ábra: A karrierlehetôségekkel való elégedettség (N: 476 fő) 
A karrier kérdéskörhöz kapcsolódóan megvizsgáltuk azt is, hogy a gyakornokok terveznek-e munkahely-változtatást, illetve pályaelhagyást. A kérdőívre adott válaszokból az olvasható ki, hogy a válaszadó gyakornokok több mint egynegyede (29\%) tervezi, hogy munkahelyet változtat (5. ábra).

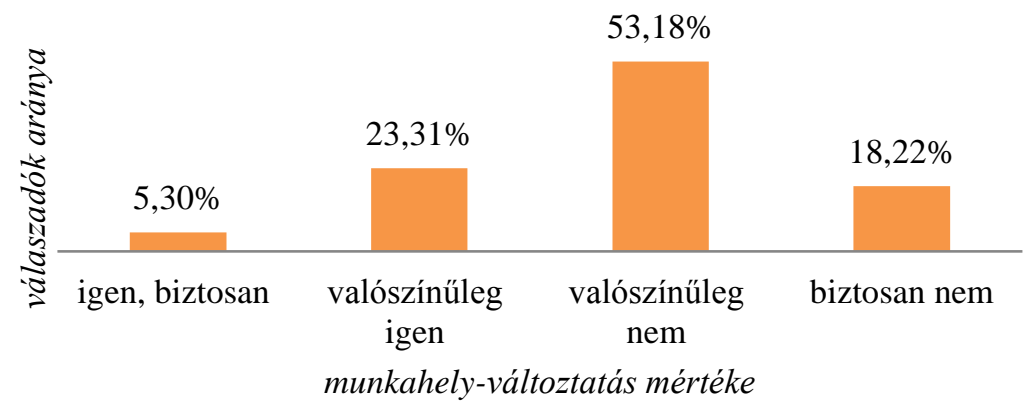

5. ábra: Tervezi-e, hogy munkahelyet változtat? (N: 472 fö)

Az esetleges munkahely-változtatás okait nyílt kérdéssel kutattuk, melyre 190 fó válaszolt. A válaszok összesen 270 közléselemet tartalmaznak, melyeket kategóriákba rendeztük. Ezek közül a legnagyobb kategóriák: az anyagi kérdések, a leterheltség (időhiány), más iskolatípus választása, a munkahely és az iskola közötti nagy távolság, a megbecsülés hiánya, a munka személyi és tárgyi körülményei.

Elgondolkodtató adat, hogy a megkérdezetteknek csupán 18\%-a válaszolta azt, hogy biztosan nem változtatna munkahelyet. Tehát 72\%-uk foglalkozott már valamilyen szinten a munkahelyváltás gondolatával. A munkahelyet váltani kívánó gyakornok válaszadók több mint a fele (54\%) úgy véli, hogy az új munkahelye kapcsolódna a pedagógusvégzettséghez, majdnem egyharmaduk (32\%) szerint csak részben kapcsolódna. 14\% (a teljes mintában 10\%) egészen más területen helyezkedne el, vagyis ök valószínüleg pályaelhagyók lesznek.

A jövőre vonatkozó kérdésre válaszadó 473 gyakornokok több mint négyötöde (84\%) úgy gondolja, hogy a pedagógusi pályán lesz öt év múlva, 73\%-uk pedig tíz év múlva is. A pályakezdők $8 \%$-a úgy véli, hogy valószínüleg nem vagy biztosan nem lesz a pályán öt év múlva, tíz év múlva pedig már $13 \%$ ez az arány (6. ábra). A válaszadó pályakezdő pedagógusok többsége tehát valószínűleg iskolákban fog dolgozni, vagyis komolyan hosszú távú tervekkel rendelkezik a pedagógusi karrierjével kapcsolatban. A pályakezdés nehézségei ellenére a pedagógusi pálya mégis vonzó lehet azzal, hogy pozitív értékeket közvetít, hogy nyitva áll bármelyik társadalmi csoport elött, hogy relatív biztonságot nyújt a pálya elöre haladtával. Abban, hogy a pedagógusok milyennek értékelik a karrierjüket, karrierlehetőségeiket, az is közrejátszik, hogy mi volt a pályaválasztásuk motivációja. 


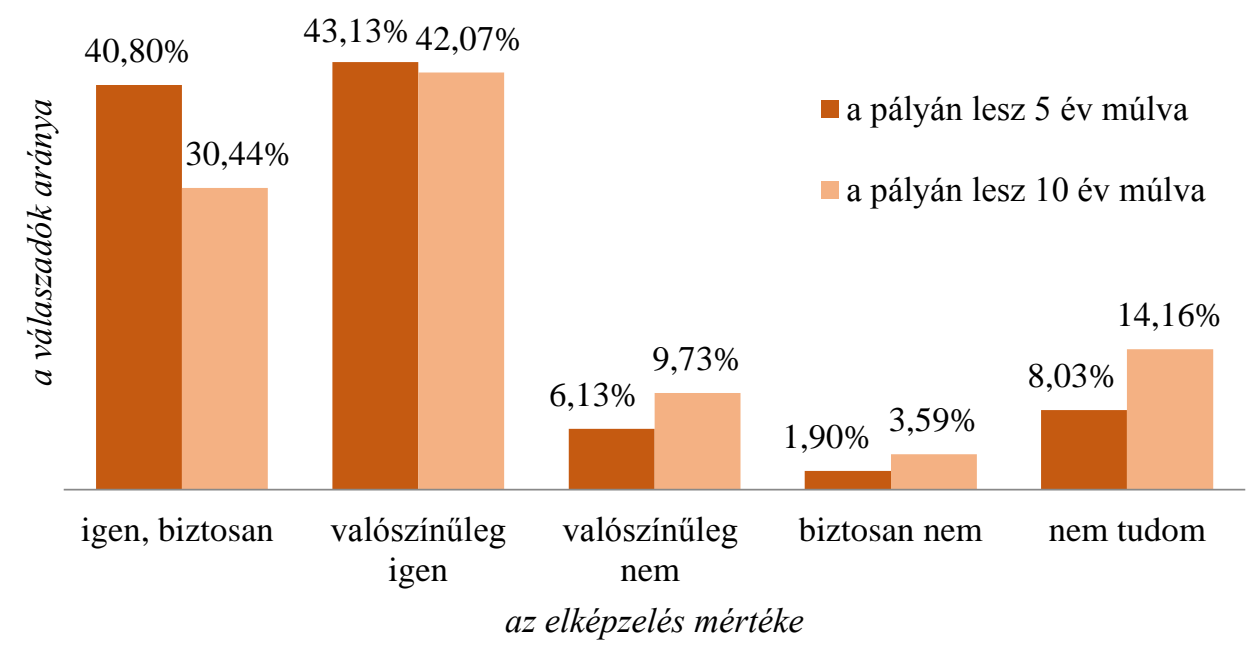

6. ábra: A pedagógusi pályán képzeli el magát öt vagy tíz év múlva? (N: 473 fö)

Azok a válaszadó pályakezdő pedagógusok, akik úgy választottak pályát, hogy érdekelte őket ez a szakterület, vagyis tudatosan készültek rá, várhatóan még nagyobb arányban maradnak majd a pályán. Válaszaik szerint öt év múlva $86,87 \%$ uk és tíz év múlva 76,25\%-uk lesz még valószínüleg a pályán (7. és 8. ábra).

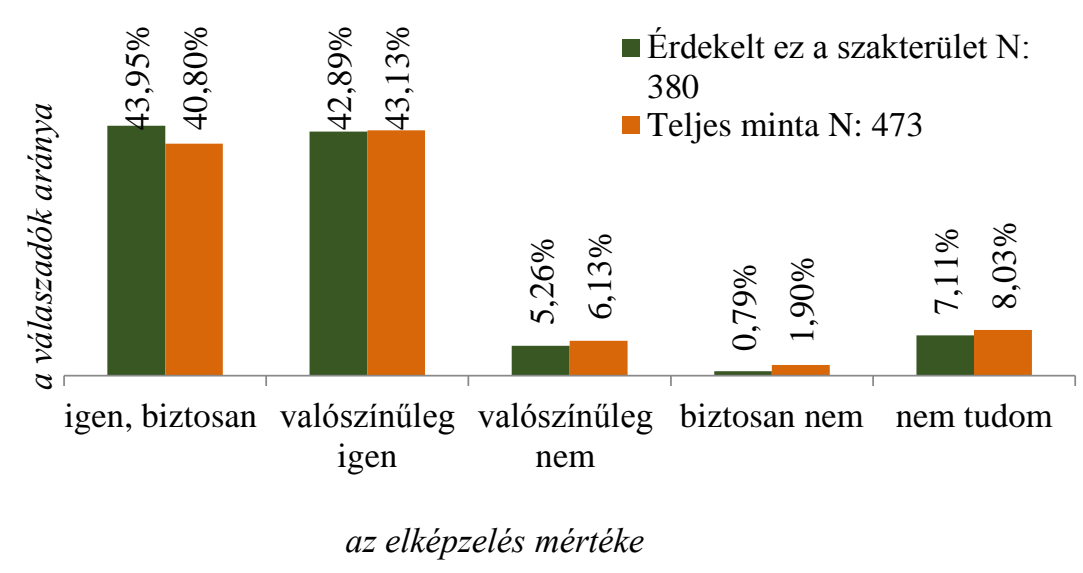

7. ábra: A pedagógusi pályán képzelik-e el magukat a „tudatos” pályaválasztók öt év múlva a teljes mintához viszonyítva? (N: 473 fö) 


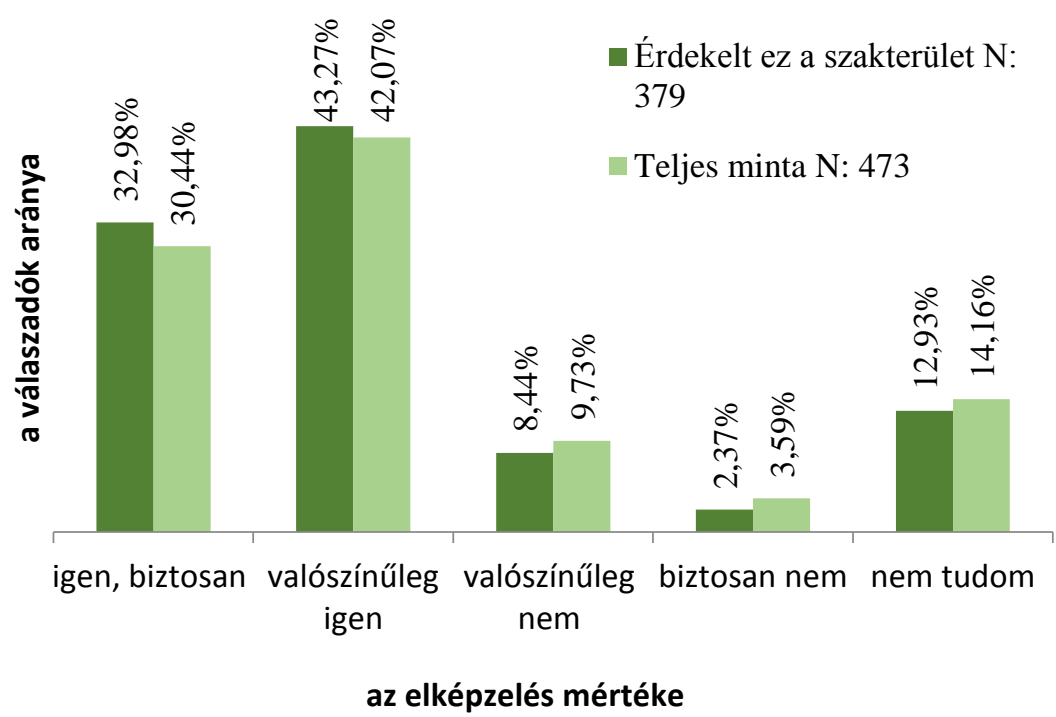

8. ábra: A pedagógusi pályán képzelik-e el magukat a „tudatos” pályaválasztók tíz év múlva a teljes mintához viszonyítva? (N: 473 fö)

\section{Karriertervek a pedagógus életpálya modellben}

A továbbiakban megvizsgáltuk, hogy milyen karriertervekkel rendelkeznek a megkérdezett gyakornokok a pedagógus-életpályamodellben. A válaszadó gyakornok közel egytizede hosszú távú céljai között a Pedagógus I. fokozatot jelöli meg. Ez az a fokozat az életpályamodellben, amelyben legfeljebb kilenc évig lehet a pedagógus. Vagyis ezt a kategóriát megjelölők vagy csak legfeljebb 11-13 évre tervezik a pedagógusi pályájukat a gyakornoki idővel együtt, vagy nem kellően ismerték az életpálya modellt. A Pedagógus II. fokozat tehát a pedagógus életútjában minimumnak tekinthető. A válaszadók 44\%-ának szerepel e fokozat az elérendő karriertervei között. Ők azok, akik szándékaik szerint biztosan a pályán maradnak és tanítani fognak.

Szakvizsgához és további minősítő eljáráshoz kötött mesterpedagógus a gyakornokok több mint egyharmada (36\%) szeretne lenni. Rendszeresen publikáló, fejlesztő, doktori fokozattal rendelkező kutatótanári fokozatot pedig a pályakezdők több mint egytizede (11\%) tervezi jelenleg.

Vezető szeretne lenni a válaszadó pályakezdő pedagógusok alig több mint egyötöde (21\%). A válaszoló gyakornokok többsége (68\%) azonban úgy gondolja, hogy nem szeretne vezető lenni. 23\%-uk biztosan nem, $11 \%$-uk pedig nem tudja. Tehát az intézményvezetés csak kevés válaszadó gyakornok esetében szerepel a karrierterveik között. 
A szakmai fejlödés tervei

A pedagógusoknak fel kell készülniük az egész életen át tartó tanulásra. A köznevelési törvény életpályamodellje és továbbképzési elöírásai mellett sokkal inkább azért, mert a közoktatási változásoknak, a társadalom kihívásainak csak a folyamatosan és sokoldalúak képzett pedagógusok tudnak majd megfelelni.

Az eredmények azt mutatják, hogy a megkérdezettek érzik a továbbképzések szükségességét. Több mint 70\%-uk szerint nagymértékben vagy nagyon nagymértékben van egy pályakezdőnek szüksége továbbképzésre. Mindössze kevesebb, mint 5\%-uk véli úgy, hogy egyáltalán nem kell továbbképzés egy gyakornoknak. Döntő többségük $(88 \%)$ biztosan vagy valószínűleg jelentkezne továbbképzésre. Csupán 2\%-uk nem jelentkezne a jövőben továbbképzésekre. A továbbképzések listája és a válaszadók preferenciái a 9. ábrán látható. A pedagóguséletpályamodellben a Mesterpedagógus fokozathoz szakvizsga, a Kutatótanárihoz pedig a pedagógiai tevékenységhez kapcsolódó tudományos fokozat szükséges. E karriertervek megvalósításához szükséges szakvizsgához kapcsolódó képzésre vagy doktori képzésre is a gyakornokok majdnem tíz-tíz százaléka jelentkezne.

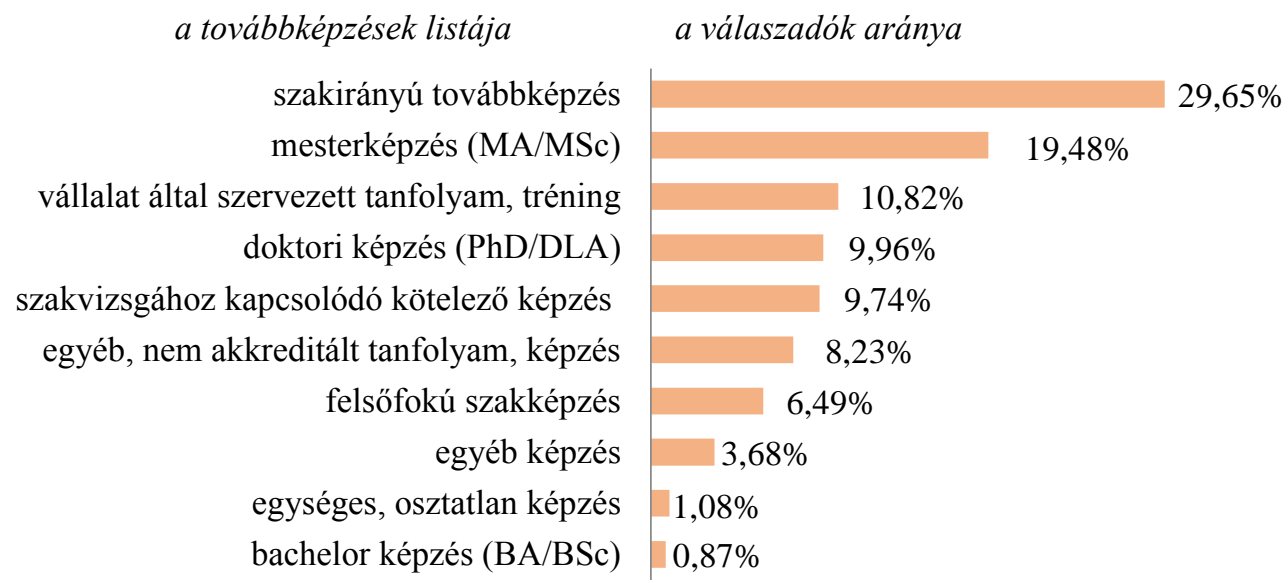

9. ábra: Milyen típusú továbbképzés érdekelné? (N: 462 fö) (az ábra százalékos megoszlásai a továbbképzéseket nem elutasító gyakornokokra vonatkoznak)

Sági Matild (Sági, 2015) kutatásában egy nagyon érdekes jelenségre hívta fel a figyelmet: a pedagógus-életpályamodell hatására a pedagógusok sokasága „mozdult meg”. Új képzettséget szereztek, változtattak tevékenységeik struktúráján, felkészültek a változásokra. Megállapította, hogy a minősítési rendszer bevezetésének első éveiben a pedagógustársadalom karrierstratégiák szerint polarizálódott: a korábban is aktív, motivált, magasan kvalifikált pedagógusok 
elkezdték megszerezni azokat a végzettségeket, amelyek szükségesek az előrelépéshez az életpályamodellben, míg a korábban inaktívak, továbbra is passzívak maradtak.

\section{A kutatás összegzése}

Kutatásunkban pályakezdő pedagógusok karrierterveit vizsgáltuk abból a szempontból, hogy mennyire elégedettek az iskolai munka feltételeivel, a karrierlehetőségekkel, hogyan látják jövőjüket a pedagógus életpálya modellben, terveznek-e pályaelhagyást, illetve szeretnének-e továbbképzésekre jelentkezni.

Elsőként arra a kérdésre kerestük a választ, hogy mennyire elégedettek a megkérdezett gyakornokok a pedagógusi pálya karrierlehetőségeivel. Az eredmények azonban azt mutatták, hogy a válaszadó gyakornokok közepesen elégedettek a pedagógusi pályán elérhető karrierlehetőségekkel. A karriertervek kapcsán vizsgáltuk, hogy hosszútávon melyik fokozat elérését tüzték ki célul a megkérdezettek a pedagógus-életpályamodellben. A megkérdezett pályakezdő pedagógusok majdnem fele hosszú távon a Pedagógus II. fokozatba szeretne kerülni.

A kutatás másik hangsúlyos kérdése az volt, hogy a pedagógusi pályán képzelik-e el a jövőjüket a válaszadó gyakornokok. Az eredmények azt mutatják, hogy terveik szerint a pályakezdők jelentős része úgy véli, hogy a pedagógusi pályán lesz öt, illetve 10 év múlva is. Továbbá megállapítottuk, hogy azok a pályakezdő pedagógusok, akik tudatosan készültek a pedagógusi pályára, hosszú távon is ott akarnak dolgozni.

Elgondolkodtató adat azonban, hogy a válaszadó gyakornokok háromnegyedében felmerült már, hogy munkahelyet változtat. Egynegyedük tervezi jelenleg, hogy más munkahelyet keres. Megvizsgálva a munkahely-változtatási okokat, azt az eredményt kaptuk, hogy legtöbben az alacsony jövedelmeket, a leterheltséget, valamint a számukra nem megfelelő vagy távol elhelyezkedő munkahelyüket jelölték meg. A gyakornokok többsége azonban úgy véli, hogy ha változtatna is, az új munkahelye részben vagy egészében kapcsolódna a pedagógusi végzettségéhez.

Figyelemreméltó adat továbbá, hogy a gyakornokoknak csak 70 százaléka gondolja úgy, hogy a pályakezdőknek nagy szükségük van továbbképzésekre, ugyanakkor az összes gyakornok 88 százaléka szándékozik továbbképzésre jelentkezni. Leginkább a szakirányú továbbképzések és a mesterképzések érdeklik őket. A válaszadó gyakornokok egyötöde doktori vagy szakvizsgára felkészítő képzések iránt érdeklődik. Tehát fontosnak tartják kihasználni a szakmai fejlődési lehetőségeket.

Kutatásunk eredményei rámutattak, hogy érdemes odafigyelni a pedagógusi pálya első szakaszára, hiszen ez meghatározó a későbbi pálya szempontjából. Lényeges, hogy a pályakezdők „ne süllyedjenek el a mélyvízben”, hogy ne riassza el őket a „valóságsokk”. A kutatásban részt vevő gyakornokok közepesen 
elégedettek a karrierlehetőségekkel, többségüket már foglalkoztatta a munkahelyváltoztatás gondolata. Jogosan merülhet fel a kérdés, hogy vajon a pedagógusi pályán maradnak-e, illetve amennyiben igen, akkor hogyan sikerül helytállniuk pedagógusként. A mentor szerepe meghatározó lehet a gyakornokok segítésében. Fontos információk lehetnek számukra is, hogy mennyire elégedettek a pályakezdők a karrierlehetőségekkel, hogy mi az, ami eltántorítja, illetve a pályán tarthatja a fiatal generációt, milyen elképzelésekkel rendelkeznek a jövőre vonatkozóan, ezek figyelembevételével hogyan lehet segítséget nyújtani számukra a pályakezdés nehézségeinek áthidalásában.

\section{Irodalom}

Berliner, D. C. (2005): Szakértő tanárok viselkedésének leírása és teljesítményeik dokumentálása. Pedagógusképzés, 2. sz. 71-92.

Chrappán Magdolna (2010): Pályaelégedettség és karriertervek a pedagógus képzettségü hallgatók körében. In: Chrappán Magdolna és mtsai (2010): Diplomás pályakövetés IV. Frissdiplomások 2010. Educatio Társadalmi Szolgáltató Nonprofit Kft, Budapest. https://www.felvi.hu/pub_bin/dload/DPR/dprfuzet4/Pages267_286_Chrappan.pdf Letöltés ideje: 2014. szeptember 8.

Falus Iván (2004): A pedagógussá válás folyamata. Educatio, 3. sz. 359-374.

Falus Iván (2006): A tanári tevékenység és a pedagógusképzés útjai. Gondolat Kiadó, Budapest.

Falus Iván (2010): A pedagógusképzés korszerüsítése - európai tendenciák. Pedagógusképzés, 1. sz. 19-36.

Holecz Anita - Molnár Szandra (2014): Pedagógusok pozitív pszichológiai tükörben: a jóllétet erősítő tényezők jellemzői a pályán. Iskolakultúra, 10. sz. 3-14.

Holik Ildikó (2014): A pedagógusi pálya aktuális kérdései gender-szempontú megközelítésben. In: Juhász Erika - Kozma Tamás (szerk.): Oktatáskutatás határon innen és túl. Belvedere Meridionale, Szeged. 154-177.

Holik Ildikó (2015): Mentortanárok oktatási módszerei. Neveléstudomány, 4. sz. 22-37.

Hunya Márta - Simon Gabriella (2013): A gyakornokok támogatása. Szakirodalmi összefoglaló. Oktatáskutató és Fejlesztő Intézet, Budapest.

Imre Nóra - Nagy Mária (2003): Pedagógusok. In: Halász Gábor - Lannert Judit: Jelentés a magyar közoktatásról 2003. Országos Közoktatási Intézet, Budapest. 273-307.

Karras, K. G. - Wolhuter, C. C. (Eds., 2015): International Handbook of Teacher Training and Re-training Systems in Modern World. HM Studies and Publishing, Nicosia, Cyprus.

Kolozsváry Judit (2006): Tanítók és gyermekek a huszonegyedik század iskolájában. In: Szabó Mária (szerk.): A jövő elöszobája. Tanulmányok a közoktatás kezdöszakaszáról. Országos Közoktatási Intézet, Budapest. 165-186.

Köcséné Szabó Ildikó (2009): Módszertan. A tanári mesterség alapjai c. tárgyból. http://pszk.nyme.hu/tamop412b/tanari_mesterseg_alapjai/index.html Letöltés ideje: 2014. október 5.

Kubinger-Pillmann Judit (2011): Mentorfórum - Mentorképzés. Iskolakultúra, 12. sz. 111113. 
Lesznyák Márta (2005): A mentortanár szerepe a szakmai szocializációban és feladatai. In: Útmutató az általános pedagógiai gyakorlatban résztvevö mentortanárok számára. Kézirat SZTE, Neveléstudományi Tanszék, Szeged.

Nagy Mária (2004): Pályakezdés, mint a pedagógusképzés középső fázisa. Educatio, 3. sz., 375-390.

Paksi Borbála - Schmidt Andrea - Magi Anna - Eisinger Andrea - Felvinczi Katalin (2015): Gyakorló pedagógusok pályamotivációi. Educatio,1. sz. 63-82.

Sági Matild (2015): Pedagógus karrierminták. Educatio,1. sz. 83-97.

Sallai Éva (2015): A mentori tevékenységek tapasztalatai. In: Sallai Éva (szerk.): A pedagógusok gyakornoki rendszerének fejlesztése és értékelése. Oktatási Hivatal, Budapest. 45-86.

Stéger Csilla (2010): A pályakezdő tanárok bevezető támogatási rendszerével kapcsolatos uniós törekvésekről. Pedagógusképzés, 1. sz. 37-56.

Szabó Ildikó (1998): Tanárok szakma- és szerepfelfogása a kilencvenes években. In: Nagy Mária (szerk.): Tanári pálya és életkörülmények. Okker Kiadó, Budapest. 145-175.

Szivák Judit (1999): A kezdő pedagógus. Iskolakultúra, 4. sz. 3-13.

Szivák Judit - Lénárd Sándor - Rapos Nóra (2011): Mentor és tanárjelölt az összefüggő egyéni gyakorlaton - módszertani ajánlás. In: M. Nádasi Mária (szerk.): A mentorfelkészités rendszere, próbája, a mentorképzés szakterületi elökészitése. III. A mentorképzés tartalmáról. ELTE Eötvös Kiadó, Budapest. 17-37.

Szücs Norbert - Fejes József Balázs (2010): A deszegregációs intézkedéseket támogató hallgatói Mentorprogram lehetőségei a pedagógusképzésben. In: Albert Gábor (szerk.): Az óvodapedagógiától az andragógiáig: Képzés és Gyakorlat Konferencia III. Kaposvári Egyetem Csokonai Vitéz Mihály Pedagógiai Főiskolai Kar, Kaposvár. 113-125.

Tordai Zita (2015): A mentortanári feladatokra való felkészülés vizsgálata a tanári kompetenciák tükrében. Neveléstudomány, 4. sz. 5-21.

Útmutató a pedagógusok minösitési rendszeréhez. Oktatási Hivatal, Budapest, 2013 http://www.oktatas.hu/pub_bin/dload/unios_projektek/kiadvanyok/utmutato_a_peda gogusok_minositesi_rendszereben_3jav.pdf Letöltés ideje: 2014. október 7.

2011. évi CXC törvény a nemzeti köznevelésröl. http://net.jogtar.hu/jr/gen/hjegy_doc.cgi?docid=A1100190.TV Letöltés ideje: 2014. október 5.

326/2013. (VIII. 30.) Korm. rendelet a pedagógusok elömeneteli rendszeréröl és a közalkalmazottak jogállásáról szóló 1992. évi XXXIII. törvény köznevelési intézményekben történö végrehajtásáról.

http://net.jogtar.hu/jr/gen/hjegy_doc.cgi?docid=A1300326.KOR Letöltés ideje: 2016. április 27. 